\title{
Is there a role for pyloric exclusion after severe duodenal trauma?
}

\section{Existe lugar para a exclusão pilórica no trauma duodenal grave?}

\author{
José Cruvinel Neto'; Bruno Monteiro Tavares Pereira ${ }^{1}$; Marcelo Augusto Fontenelle Ribeiro JR. ${ }^{2}$, TCBC-SP; Sandro Rizoli3; \\ Gustavo Pereira Fraga², tCBC-SP; João Baptista Rezende-Neto ${ }^{4}$
}

\section{A B S T R A C T}

\begin{abstract}
Duodenal trauma is an infrequent injury, but linked to high morbidity and mortality. Surgical management of duodenal injuries is dictated by: patient's hemodynamic status, injury severity, time of diagnosis, and presence of concomitant injuries. Even though most cases can be treated with primary repair, some experts advocate adjuvant procedures. Pyloric exclusion (PE) has emerged as an ancillary method to protect suture repair in more complex injuries. However, the effectiveness of this procedure is debatable. The "Evidence Based Telemedicine - Trauma \& Acute Care Surgery" (EBT-TACS) Journal Club performed a critical appraisal of the literature and selected three relevant publications on the indications for PE in duodenal trauma. The first study retrospectively compared 14 cases of duodenal injuries greater than grade II treated by PE, with 15 cases repaired primarily, all of which penetrating. Results showed that PE did not improve outcome. The second study, also retrospective, compared primary repair (34 cases) with PE (16 cases) in blunt and penetrating grade $>\|$ duodenal injuries. The authors concluded that PE was not necessary in all cases. The third was a literature review on the management of challenging duodenal traumas. The author of that study concluded that PE is indicated for anastomotic leak management after gastrojejunostomies. In conclusion, the choice of the surgical procedure to treat duodenal injuries should be individualized. Moreover, there is insufficient high quality scientific evidence to support the abandonment of PE in severe duodenal injuries with extensive tissue loss.
\end{abstract}

Key words: Wounds and injuries. Morbidity. Anastomosis, surgical. Duodenum. Gastroenterostomy.

\section{INTRODUCTION}

$\mathrm{D}$ uodenal injuries occur in 3 to $5 \%$ of all abdominal traumas. Albeit uncommon, these injuries are linked to high morbidity and mortality rates. Approximately $75 \%$ of duodenal injuries are caused by penetrating trauma ${ }^{1-3}$. Blunt duodenal injuries pose significant diagnostic challenge and require high suspicion.

According to the American Association for the Surgery of Trauma (AAST) grading system, as well as to trauma literature, duodenal injuries greater than grade II are considered severe ${ }^{1-4}$. Even though approximately $80 \%$ of duodenal injuries can be safely repaired primarily, the management of severe injuries remains controversial. Among surgical options to treat severe injuries are: primary repair alone, primary repair and decompressive tube duodenostomy, duodenal diverticulization, pyloric exclusion (PE), and duodenopancreatectomy (Whipple procedure). PE was devised by Jordan and first reported by Vaughan et al..$^{5}$ in 1977 . The procedure consists of duodenal repair, over-sewing of the pylorus through a gastrotomy, followed by a gastrojejunostomy at the site of the gastrotomy, without a vagotomy. PE provides effective duodenal exclusion, thus protecting the duodenal repair. However, this is considered an ulcerogenic technique. Several authors advocate the use of PE and consider it to be the procedure of choice in patients with severe duodenal trauma ${ }^{5-7}$. A study by Degiannis et al. ${ }^{6}$ showed a postoperative fistula rate of $43 \%(6 / 14)$ among patients who underwent primary repair and 12\% (2/17) among those who underwent PE in severe duodenal injuries provoked by penetrating trauma. The authors

EBT-TACS Meeting on June $10^{\text {th }}, 2014$, with the participation of the following services: St. Michael' Hospital, University of Toronto, Toronto, Canada; Division of Trauma Surgery, Department of Surgery, School of Medical Sciences, University of Campinas, Campinas, SP, Brazil; Division of Surgery, Santo Amaro University- UNISA, Santo Amaro, SP, Brazil.

1. Assistant Surgeon, Division of Trauma Surgery, Department of Surgery, School of Medical Sciences, University of Campinas, Campinas, SP, Brazil; 2. Master in Surgery. Professor, Division of Trauma Surgery, Department of Surgery, School of Medical Sciences, University of Campinas, Campinas, SP, Brazil; 3. TCBC-SP, FACS. Full Professor; Head, Division of Surgery, Santo Amaro University - UNISA; 4. FRCSC, FACS. Full Professor, Department of Surgery and Critical Care Medicine, University of Toronto; Director, Trauma, St Michael's Hospital, Toronto, Canada; 5. TCBC-SP, FACS. Coordinating Professor, Division of Trauma Surgery, Department of Surgery, School of Medical Sciences, University of Campinas, Campinas, SP, Brazil; 6. TCBC-MG, FACS. Associate Professor, Surgery, University of Toronto, Trauma and Acute Care General Surgeon, St Michael's Hospital, Surgeon-Investigator, Keenan Research Centre for Biomedical Science and Li Ka Shing Knowledge Institute, Toronto, Canada. 
concluded that grade III gunshot injuries to the duodenum should always be treated with $\mathrm{PE}^{6}$. Notwithstanding, others have reported a trend towards higher overall complication rates with PE. Hence, a "less is better" approach in duodenal trauma has emerged ${ }^{7-10}$.

The participants of the EBT-TACS Journal Club analyzed the current literature and, based on panel discussions, generated recommendations on the role of PE in the management of duodenal injuries.

\section{STUDY 1}

"A ten-year retrospective review: does pyloric exclusion improve clinical outcome after penetrating duodenal and combined pancreaticoduodenal injuries?"8

\section{Rationale}

The infrequency of duodenal injuries in trauma has hampered broad-based consensus with respect to the choice of the most appropriate surgical procedure in severe duodenal injuries. Duodenal diverticulization and pyloric exclusion have been used to protect suture repair in such cases. However, those procedures increase operative time and entail high morbidity.

\section{Question}

Does pyloric exclusion improve the clinical outcome of patients who sustain penetrating duodenal injuries in spite of longer operative time and higher morbidity?

\section{Main findings}

Medical records of 54 patients with duodenal injuries from January 1995 to December 2004 were retrospectively reviewed. Injuries were graded as per the American Association for the Surgery of Trauma - Organ Injury Scale 4 . Twenty five patients were excluded for multiple reasons. The remaining 29 patients were included in the study; all had duodenal injuries grade II or more, with or without concomitant pancreatic injuries. Fifteen were treated by primary repair and 14 underwent PE. Hemorrhagic shock was present in $33 \%$ of patients with primary repair and in $21 \%$ of those who underwent PE. The ISS was 18.4 in patients who underwent primary repair and 23.2 in PE. Grade II injuries were present in 9 patients, 6 of them were treated with primary repair; 16 patients sustained grade III injuries, 8 of them were treated by primary repair. All grade IV patients underwent PE. Combined duodenalpancreatic injuries were present in 13 patients, only 3 of them undergoing primary repair.

Regardless of the procedure, none of the patients developed duodenal fistulas. However, $70 \%$ of those who underwent pyloric exclusion presented with post-operative complications (ARDS, acute renal failure, abscesses, sepsis), compared with $33 \%$ of patients with primary repair. Hospital length of stay (LOS) was also higher in PE patients compared with those with primary repair; 24.3 vs. 13.5 days, respectively.

\section{Strenghts}

Inclusion criteria were well defined, thus reducing selection bias.

Results showed that primary repair is safe in severe penetrating duodenal injuries, and is potentially linked to lower complication rates and shorter hospital LOS when compared with PE.

\section{Limitations}

It was a retrospective study with no long-term follow up. It had a small sample size, which did not provide statistical significance.

There was a trend to perform PE in more severe duodenal injuries and in those with concomitant pancreatic trauma. The latter is definitely linked to higher complication rates.

\section{STUDY 2}

$$
\text { "Safety of repair for severe duodenal injuries"9 }
$$

\section{Rationale}

There is no Level I evidence to strongly recommend a most appropriate surgical procedure in severe duodenal injuries. Moreover, the safeness of primary repair has been questioned.

\section{Question} safe option?

Is primary repair of severe duodenal injuries a

\section{Main findings}

This was a retrospective analysis of 193 medical charts of patients who presented with duodenal injuries from 1992 to 2004 in a single institution. Only 50 patients were included in the study, all having sustained severe duodenal injury (SDI).

Patients were divided into two groups. Group 1: PR (primary repair $-\mathrm{n}=34$ ). Group 2: PE (pyloric exclusion $n=16)$.

PR patients had a higher incidence of injuries on the first and the second portions of the duodenum (79\% vs. $42 \%, p=0.02$ ), and a non-significant trend towards more severe injuries (grade IV and V - 37\% vs. 18\%, $p=0.11$ ). There were no outcome differences between the two groups. Six PR patients (18\%) and four PE ones (25\%) developed complications presumably related to the surgical procedure; all 10 patients had duodenal leaks, eight of those being managed by intra-abdominal drains placed at the initial procedure or by post-operative CT-guided drainage; only 2 patients required re-operation. One patient developed a marginal ulcer at the gastrojejunostomy site. 
There were no cases of duodenal bleeding or obstruction at the repair site.

Among the patients with associated pancreatic injury, the rate of duodenal leak was 30\% (3/10) in the PE group and $11 \%(1 / 9)$ in the PR group.

\section{Strenghts}

The $20 \%$ incidence of postoperative complications directly correlated with the repair of severe duodenal injuries is in keeping with other reports.

Even though the anastomotic leak rate paralleled duodenal injury severity (12\% in grade III injuries vs. $43 \%$ in grades IV and V injuries), there was no correlation with the surgical technique used for repair. The high incidence of overall postoperative complications (66\%) demonstrates that duodenal injury is a marker of severe trauma, and supports other studies and literature reviews.

This study is the largest review focused exclusively on surgical management of severe duodenal injuries, albeit retrospective.

\section{Limitations}

Small sample size precluded statistical significance between the outcomes investigated.

It was a retrospective, single-center study.

There was preference towards the use of primary repair in the institution where the study was performed, and PE was more often used to treat severe injuries.

This study does not support the use of either PE or PR in severe duodenal injuries.

\section{STUDY 3}

Duodenal Injury" 3

"The Therapeutic Challenges in Treating

\section{Rationale}

Management of severe duodenal injuries can be extremely challenging. Intra-operative decision regarding the most appropriate surgical procedure is based on the location and degree of injury, associated traumas, and the patient's clinical condition. Adequate decision making is of utmost importance and directly impacts morbidity and mortality rates.

\section{Question}

How to minimize complications in severe duodenal injuries?

\section{Main findings}

The author describes basic principles involved in the surgical management of duodenal injuries. The impact of injury location on surgical decision is emphasized, particularly for injuries to the second and third portions of the duodenum. Moreover, the author also discusses the most frequently used diagnostic methods in duodenal trauma. With respect to surgical procedures, the "triple tube" technique is revisited, consisting of a gastrostomy and a retrograde jejunostomy, both used for decompression, performed in conjunction with a feeding jejunostomy.

Technical changes in the technique of duodenal diverticulization are described. Vagotomy is unnecessary, and T-tube insertion into the common bile duct for decompression should be only be used in associated pancreaticobiliary injuries. Injuries that result in transection of the head and neck of the pancreas may require suture of the cephalic remnant and a Roux-en-Y end-to-side pancreaticojejunostomy of the distal pancreas. The pyloric exclusion technique is also discussed. However, in the author's experience, the most common adjuvant procedure to primary repair of the laceration was duodenal diverticulization without vagotomy.

\section{Strenghts}

Expert opinion on the management of severe duodenal injuries.

\section{Limitations \\ This was basically a review study. \\ There were no objective comparative data.}

\section{CONCLUSIONS}

Severe injuries to the duodenum are uncommon, and usually result from penetrating trauma. The majority of those injuries can be treated with PR and drainage. Even though PE entails high morbidity compared with PR, it is conceivable that the former could protect the duodenal suture repair. Therefore, PE may be useful in selected cases of severe duodenal injuries. The EBT-TACS group critically appraised two retrospective studies with small series and one review addressing the role of PE. However, further investigation in large randomized prospective trials are needed to formulate a robust recommendation. We conclude that the indications for EP should be more restricted, and that primary repair is a safe option in the majority of patients. Furthermore, there is insufficient scientific evidence to forsake the use of PE.

\section{RECOMMENDATIONS}

Recommendations for the use of PE in the surgical management of severe duodenal injuries are:

1. There is limited use for $P E$, such as for injuries with extensive tissue loss.

2. Simple repair and drainage is both adequate and safe for most duodenal injuries.

3. There is insufficient high quality scientific evidence to forsake the use of PE. 


\title{
R E S U M O
}

\begin{abstract}
O trauma duodenal é incomum, mas possui alta morbimortalidade. As condições clínicas dos pacientes, gravidade das lesões, tempo de diagnóstico e lesões associadas influenciam na escolha do procedimento operatório. A maioria das lesões duodenais é tratada com reparo primário. Procedimentos adjuvantes para proteger a linha de sutura e evitar deiscência podem ser úteis em lesões complexas. Embora a exclusão pilórica (EP) seja utilizada em lesões duodenais graves, há controvérsia quanto a sua necessidade. A reunião "Telemedicina Baseada em Evidências - Cirurgia do Trauma e Emergência" (TBE-CITE) revisou a literatura e selecionou três publicações relevantes sobre as indicações de EP no trauma duodenal. O primeiro estudo, retrospectivo, comparou 14 pacientes com ferimentos penetrantes duodenais grau > II, tratados com EP, com 15 pacientes semelhantes tratados com reparo primário; não houve diferença nos resultados. O segundo, também retrospectivo, comparou o reparo primário (34 casos) com EP (16 casos), em lesões duodenais contusas ou penetrantes grau > II. Os autores concluíram que a EP não é necessária para todos os pacientes, apesar de lesões duodenais graves. O terceiro estudo constituiu-se de revisão da literatura sobre os desafios do tratamento dos traumatismos duodenais. Na experiência do autor, a EP é útil nos casos de fístula de anastomoses gastrojejunais. Conclui-se que a escolha do procedimento operatório no tratamento das lesões duodenais deve ser individualizada. Não há evidência cientifica de boa qualidade para justificar o abandono da EP no tratamento das lesões duodenais graves com grande perda tecidual.
\end{abstract}

Descritores: Ferimentos e lesões. Morbidade. Anastomose cirúrgica. Duodeno. Gatroenterostomia.

\section{REFERENCES}

1. Asensio JA, Feliciano DV, Britt LD, Kerstein MD. Management of duodenal injuries. Curr Probl Surg. 1993;30(11):1023-93.

2. Fraga GP, Biazotto G, Villaça MP, Andreollo NA, Mantovani M Trauma de duodeno: análise de fatores relacionados à morbimortalidade. Rev Col Bras Cir. 2008;35(2):94-102.

3. Lucas CE. The therapeutic challenges in treating duodenal injury. Pan J Trauma. 2013;2(3):126-33.

4. Moore EE, Cogbill TH, Malangoni MA, Jurkovich GJ, Champion HR, Gennarelli TA, et al. Organ injury scaling, II: Pancreas, duodenum, small bowel, colon, and rectum. J Trauma. 1990;30(11):1427-9.

5. Vaughan GD, Frazier OH, Graham DY, Mattox KL, Petmecky FF, Jordan GL. The use of pyloric exclusion in the management of severe duodenal injuries. Am J Surg. 1977;134(6):785-90.

6. Degiannis E, Krawczykowski D, Velmahos GC, Levy RD, Souter I, Saadia R. Pyloric exclusion in severe penetrating injuries of the duodenum. World J Surg. 1993;17(6):751-4.

7. Fraga GP, Biazotto G, Bortoto JB, Andreollo NA, Mantovani M. The use of pyloric exclusion for treating duodenal trauma: case series. Sao Paulo Med J. 2008;126(6):337-41.
8. Seamon MJ, Pieri PG, Fisher CA, Gaughan J, Santora TA, Pathak AS, et al. A ten-year retrospective review: does pyloric exclusion improve clinical outcome after penetrating duodenal and combined pancreaticoduodenal injuries? J Trauma. 2007;62(4):829-33.

9. Velmahos GC, Constantinou C, Kasotakis G. Safety of repair for severe duodenal injuries. World J Surg. 2008;32(1):7-12.

10. Ordoñez C, García A, Parra MW, Scavo D, Pino LF, Millán M, et al Complex penetrating duodenal injuries: less is better. J Trauma Acute Care Surg. 2014;76(5):1177-83.

\section{Statement}

The opinions and assertions contained herein represent the private views of the participants of the Evidence-based Telemedicine - Trauma and Acute Care Surgery (EBT-TACS) Journal Club, and are not to be construed as reflecting the views of the institutions that they represent.

Received on 05/06/2014

Accepted for publication 08/06/2014

Address for correspondence:

José Cruvinel Neto

E-mail: cruvinel.j@gmail.com 